\title{
Comparative analysis of the criteria for evaluation of complex infrastructure of the socio-economic projects in the context of digitalization
}

\author{
Irina Kryuchkova ${ }^{1, *}$, Elena Smorodina ${ }^{1}$, Oksana Belyantseva ${ }^{1}$, and Elena Serebryakova ${ }^{1}$ \\ ${ }^{1}$ Voronezh State Technical University, Moscovskiy prospect 14, Voronezh, 394026, Russia irishka-
}

\begin{abstract}
The formation and development of the waste processing industry is important in the social and economic life of society. Ensuring environmental safety, rational nature management and minimizing the negative impact of waste on the environment are priority areas for the development of the Voronezh region. Currently, the regional system for managing municipal solid waste is being modernized through the formation of inter-municipal environmental waste processing clusters (IEWC). In this regard, the need to study the issue of assessing the effectiveness of ongoing measures to form an integrated infrastructure for safe waste management is very relevant, especially in the context of digitalization. The analysis of the system of target indicators of the federal and regional levels for the disposal, disposal and disposal of waste. As a result of the study, it was concluded that environmental indicators prevail in the management system in the field of safe waste management. The team of authors examined the variety of properties and characteristics of socio-ecological clusters and, on the basis of a comparative analysis, highlighted criteria by which it is possible to assess the results of digital transformation and the efficiency of the functioning of the sphere of safe waste management in our region. Using the results of this study will make it possible to analyze and control the degree of achievement of the objectives of the regional program for the modernization of the waste management sector in order to make effective management decisions in the context of digital transformation.
\end{abstract}

\section{Introduction}

Due to the annual growth of solid municipal waste generation, the state policy of many countries is focused on rational use of natural resources, resource conservation and increasing the share of recycled and disposed garbage. Ensuring a balance between social, economic and environmental factors is a prerequisite for the sustainable development of regions.

The formation of a new system for safe waste management began in Russia just a few years ago. The regions of our country have adopted regional programs in the field of waste

\footnotetext{
* Corresponding author: kryuchkova@mail.ru
} 
management, the main goal of which is to reduce the negative impact on the environment by increasing the amount of waste involved in secondary use [1].

In the Voronezh region, several legal acts have been adopted, on the basis of which the region has been modernizing the waste processing industry since 2019. Based on the approved regional program in the field of safe waste management and the strategy of social and economic development of the Voronezh region, the environmental safety of the region is ensured by the construction of intermunicipal environmental waste processing clusters.

The cluster's vital activity is provided by interrelated elements, the effectiveness of which requires multi-criteria analysis. This is necessary for making management decisions in order to further develop the system. Under the efficiency of the waste processing cluster, we will understand the compliance of the results of the cluster elements with the goals set for the implementation of the strategy for the socio-economic development of the industry in the region.

Many scientific studies are devoted to evaluating the effectiveness of such complex economic systems as clusters, which can be divided into two groups. The first group includes research on the analysis of industrial clusters. Here we can highlight the work of Frolova I. S., who proposed a method for identifying and evaluating industrial clusters [2]. Markov L. $\mathrm{V}$. proposed a method for analyzing clusters in the region based on expert assessments and analysis of statistical data [3]. Lavrikova Yu. G. to evaluate the cluster, it suggests using such criteria as employment, concentration coefficient, and productivity coefficient [4]. Kurnosova proposed a method for evaluating the effectiveness of the aerospace cluster [5]. V.S. Prosalova's research is devoted to evaluating the effectiveness of strategic management of cluster innovation activity [7]. The second group includes studies that analyze the effectiveness of clusters in the service sector. According to Leonova LB, Koksharova V.A. [6] and Shvets I.Yu. [8] for the analysis of clusters in the service sector, other evaluation criteria are needed.

Despite the fact that the scientific works of A. A. Lebedeva, D. A. Lebedev [9], A.V. Erygina [10], O. E. Goryacheva, T. A. Smirnova and O. V. Govorina are devoted to the development of various criteria for assessing the state of the system of safe waste management [11], the formation of a unified system of criteria and indicators for the efficiency of the waste processing industry remains insufficiently studied and relevant issue.

The purpose of the work is to develop a set of evaluation criteria for the effectiveness of the formation and functioning of the waste processing industry. The object of our research is the infrastructure elements of the Voronezh IEWC.

The main idea of the work is to prove that the development of a multi-criteria and comprehensive assessment of the functioning of the IEWC is an important component for making effective management decisions for the purpose of sustainable socio-economic development of the waste processing industry and the region as a whole.

The purpose of the study was achieved by conducting a comparative analysis of existing approaches in identifying criteria for evaluating the effectiveness of environmental clusters.

\section{Experimental}


There are many scientific studies devoted to substantiating criteria for evaluating the effectiveness of environmental and economic and social measures that ensure the proper quality of the natural environment. However, the issue of forming a system of indicators of sustainable development in the sphere of safe waste management remains insufficiently studied.

Federal system-level indicators in the sphere of safe waste management approved and adopted in 2018 in Russia the Strategy of formation and development of the industry in recycling and disposal of waste, the implementation period to 2030 [12] and the Federal state program "environmental Protection for 2012-2020" [13]. According to Goryacheva O. E., Smirnova T. A. and Govorina O. V. Federal level indicators reflect only the environmental aspect, namely, the dynamics of changes in the formed, processed, neutralized and disposed waste of each hazard class in relation to 2007.

In order to minimize the impact of waste on the environment, the Voronezh region has adopted a regional program to improve the waste management system, including solid municipal waste (MSW) [14], which uses the system of indicators presented in Table 1 to assess the effectiveness of the program.

Table 1. Target indicators of the effectiveness of the waste management system in the Voronezh region [13-14].

\begin{tabular}{|c|c|c|}
\hline $\begin{array}{l}\text { Tasks of the regional } \\
\text { program }\end{array}$ & Name of indicator & Calculation of indicator / unit of measure \\
\hline \multirow{7}{*}{$\begin{array}{l}\text { Task } 1 . \text { Phased } \\
\text { reduction of waste } \\
\text { disposal }\end{array}$} & $\begin{array}{l}\text { The share of used and neutralized } \\
\text { municipal solid waste (MSW) of } \\
\text { hazard classes I - IV.. }\end{array}$ & $\begin{array}{l}\text { The ratio of the number of used and } \\
\text { neutralized MSW to the total number of } \\
\text { generated MSW (corresponding hazard } \\
\text { class), } \%\end{array}$ \\
\hline & $\begin{array}{l}\text { The number of waste sorting } \\
\text { complexes put into operation. }\end{array}$ & $\begin{array}{l}\text { Unit / year } \\
\text { It is determined on the basis of } \\
\text { monitoring the results of activities in the } \\
\text { field of waste management }\end{array}$ \\
\hline & $\begin{array}{l}\text { Percentage of MSW used as } \\
\text { secondary raw materials }\end{array}$ & $\begin{array}{l}\text { The ratio of the number of MSW } \\
\text { involved in economic turnover to the } \\
\text { total amount of MSW formed, } \%\end{array}$ \\
\hline & $\begin{array}{l}\text { Number of MSW landfills put } \\
\text { into operation }\end{array}$ & $\begin{array}{l}\text { It is determined on the basis of } \\
\text { monitoring the results of activities in the } \\
\text { field of waste management, Unit / year }\end{array}$ \\
\hline & $\begin{array}{l}\text { Percentage of MSW sent for } \\
\text { processing }\end{array}$ & $\begin{array}{l}\text { The ratio of the number of processed } \\
\text { MSW to the total amount of generated } \\
\text { MSW, \% }\end{array}$ \\
\hline & $\begin{array}{l}\text { Share of MSW directed to } \\
\text { recycling }\end{array}$ & $\begin{array}{l}\text { The ratio of the amount of MSW aimed } \\
\text { at disposal to the total amount of } \\
\text { generated MSW, \% }\end{array}$ \\
\hline & $\begin{array}{l}\text { Percentage of waste disposal } \\
\text { facilities that meet regulatory } \\
\text { requirements }\end{array}$ & $\begin{array}{l}\text { The ratio of the number of waste disposal } \\
\text { facilities that meet regulatory } \\
\text { requirements for the total number of } \\
\text { waste disposal facilities. }\end{array}$ \\
\hline $\begin{array}{l}\text { Task 2. Elimination } \\
\text { of facilities } \\
\text { negatively affecting } \\
\text { the environment. }\end{array}$ & $\begin{array}{l}\text { Percentage of unauthorized } \\
\text { disposal of municipal solid waste } \\
\text { disposed of at the end of the } \\
\text { reporting period }\end{array}$ & $\begin{array}{l}\text { The ratio of the number of objects of } \\
\text { unauthorized placement of MSW that } \\
\text { were liquidated at the end of the } \\
\text { reporting period to the total number of } \\
\text { objects of unauthorized placement of } \\
\text { MSW in the reporting period }\end{array}$ \\
\hline
\end{tabular}




\begin{tabular}{|l|l|l|}
\hline \multirow{2}{*}{} & $\begin{array}{l}\text { The total area of restored land } \\
\text { affected by accumulated } \\
\text { environmental damage }\end{array}$ & $\begin{array}{l}\text { It is determined on the basis of } \\
\text { monitoring the results of activities in the } \\
\text { field of waste management }\end{array}$ \\
\cline { 2 - 3 } & $\begin{array}{l}\text { The number of people whose } \\
\text { quality of life has improved due } \\
\text { to the elimination of } \\
\text { accumulated environmental } \\
\text { damage }\end{array}$ & $\begin{array}{l}\text { It is determined on the basis of } \\
\text { monitoring the results of activities in the } \\
\text { field of waste management }\end{array}$ \\
\hline $\begin{array}{l}\text { Task 3. Providing the } \\
\text { population with } \\
\text { accessible } \\
\text { information in the } \\
\text { field of waste } \\
\text { management. }\end{array}$ & $\begin{array}{l}\text { Number of information resources } \\
\text { in the field of waste management }\end{array}$ & $\begin{array}{l}\text { Units, } \\
\text { It is determined on the basis of } \\
\text { monitoring the results of activities in the } \\
\text { field of waste management }\end{array}$ \\
\hline
\end{tabular}

It can be concluded that most Federal and regional indicators reflect mainly the environmental effects of waste processing. The formation and development of the waste processing industry has an impact on various spheres of society and the position of system stakeholders, so it requires a more comprehensive assessment of the effectiveness of functioning [11].

According to A. A. Lebedeva and D. A. Lebedev, there are several classifications of indicators and indicators of quantitative and qualitative characteristics in the system of safe waste management [9]:

1. depending on the requirements for waste management processes (technical and economic, sanitary and hygienic, environmental indicators);

2. depending on the stage of waste management (formation, collection, transportation, recycling, waste disposal);

3. depending on the time of assessment (indicators of the current state and future state of operation of the waste management system);

4. depending on the nature of the information received (direct and indirect indicators that characterize the current and forecast state of the waste management system, respectively);

5. depending on the institutional level of control, allowing to assess the functioning of the waste management sphere at the level of the customer, contractor or at the municipal, regional or Federal levels).

The choice of criteria depends on the purpose of the study and the availability of information. For example, to assess the impact of the state of the waste processing industry on the state of the environment and the socio-economic development of the region, a system of qualitative assessment criteria can be used. According to Goryacheva O.E., Smirnova T.A. and Govorina O.V. [11], as well as Koroleva L.P. [15], in this case it is advisable to classify the indicators of the efficiency of waste processing into environmental, economic and social. They are presented in Table 2.

Table 2. Environmental, economic and social indicators for assessing the development of safe waste management $[8,11,15]$.

\begin{tabular}{|l|l|}
\hline \multicolumn{1}{|c|}{ Indicator group } & $\begin{array}{l}\text { The expected effect of the development of the sphere } \\
\text { of MSW management }\end{array}$ \\
\hline \multicolumn{2}{|c|}{ Ecological index } \\
\hline $\begin{array}{l}\text { Indicators that characterize the intensity of } \\
\text { processing }\end{array}$ & - prevention of environmental pollution; \\
\cline { 1 - 2 } $\begin{array}{l}\text { Indicators that characterize environmental } \\
\text { safety }\end{array}$ & - saving natural resources; \\
\cline { 1 - 2 } $\begin{array}{l}\text { Indicators that characterize the degree of } \\
\text { resource saving }\end{array}$ & - reducing the formation of MSW; \\
\hline
\end{tabular}




\begin{tabular}{|c|c|}
\hline \multicolumn{2}{|c|}{ Economic indicators } \\
\hline $\begin{array}{l}\text { Indicators characterizing the contribution } \\
\text { to industry and gross regional product }\end{array}$ & \multirow{2}{*}{$\begin{array}{l}\text { - an increase in regional budgets due to the payment of } \\
\text { taxes by the newly created waste sorting and waste } \\
\text { processing complexes; } \\
\text { - an increase in the share of released land occupied by } \\
\text { landfills for their use for agricultural purposes or } \\
\text { construction; } \\
\text { - the use of alternative sources of heating and electricity. }\end{array}$} \\
\hline $\begin{array}{l}\text { Indicators characterizing the level of } \\
\text { financing of the waste processing industry }\end{array}$ & \\
\hline \multicolumn{2}{|r|}{ Social indicators } \\
\hline $\begin{array}{l}\text { Indicators characterizing the emergence of } \\
\text { new jobs in the region }\end{array}$ & \multirow{2}{*}{$\begin{array}{l}\text { - reduction in unemployment; } \\
\text { - an increase in the life expectancy of the population due } \\
\text { to an improvement in the environmental situation; } \\
\text { - improvement of the aesthetic appearance of territories; } \\
\text { - the formation of a culture of waste management. }\end{array}$} \\
\hline $\begin{array}{l}\text { Indicators characterizing the awareness of } \\
\text { citizens about the functioning of the waste } \\
\text { management system }\end{array}$ & \\
\hline
\end{tabular}

The formation of an ecological waste processing cluster is influenced by many factors, among which it is especially necessary to single out the social development vector [16]. In this case, an important indicator of the social effect may be a reduction in the tariff for the collection and removal of MSW. This effect can be achieved through the innovative development of infrastructure in the field of safe waste management and the introduction of digital technologies for the collection, transportation and processing of waste. The use of such technologies also ensures the completeness, reliability and timeliness of obtaining data for calculating the performance indicators of the industry. Therefore, for a comprehensive assessment of the development of the industry, it is necessary to include a group of scientific and technical indicators.

\section{Evaluation}

Based on the conducted comparative analysis, the authors suggest using the following system of indicators and indicators to assess the status and development of the waste processing industry in the Voronezh region, which is presented in Table 3.

Table 3. System of indicators development of the sphere of safe waste management in the Voronezh region [10,11-14].

\begin{tabular}{|c|c|}
\hline Indicator group & Name of target indicators that can be included in the group \\
\hline \multicolumn{2}{|c|}{ Environmental indicators of industry development } \\
\hline \multirow{3}{*}{$\begin{array}{l}\text { Indicators characterizing the } \\
\text { intensity of processing }\end{array}$} & $\begin{array}{l}\text { Percentage of used and neutralized MSW (hazard class I - IV), } \\
\%[12]\end{array}$ \\
\hline & Share of MSW sent for processing, $\%[13,14]$ \\
\hline & Share of MSW directed to recycling, $\%[13,14]$ \\
\hline \multirow{5}{*}{$\begin{array}{l}\text { Indicators that characterize } \\
\text { environmental safety }\end{array}$} & $\begin{array}{l}\text { Number of waste sorting complexes put into operation, units } \\
{[13,14]}\end{array}$ \\
\hline & $\begin{array}{l}\text { Percentage of waste disposal facilities that meet regulatory } \\
\text { requirements, } \%[13,14]\end{array}$ \\
\hline & $\begin{array}{l}\text { The share of objects of unauthorized placement of solid } \\
\text { municipal waste, liquidated at the end of the reporting period, \% } \\
{[13,14]}\end{array}$ \\
\hline & $\begin{array}{l}\text { The area of restored objects exposed to the negative impact of } \\
\text { accumulated environmental damage, ha }[13,14]\end{array}$ \\
\hline & The share of MSW directed to disposal, \% [11] \\
\hline
\end{tabular}




\begin{tabular}{|c|c|}
\hline & Ratio of liquidated to accumulated landfills, $\%[10]$ \\
\hline \multirow{2}{*}{$\begin{array}{l}\text { Indicators that characterize the } \\
\text { degree of resource saving }\end{array}$} & The share of MSW used as secondary raw materials, $\%[13,14]$ \\
\hline & The number of MSW produced per capita, kg / person [11] \\
\hline \multicolumn{2}{|c|}{ Economic indicators of the industry development } \\
\hline \multirow{3}{*}{$\begin{array}{l}\text { Indicators that characterize the } \\
\text { contribution to industry and the } \\
\text { gross regional product }\end{array}$} & $\begin{array}{l}\text { Number of waste sorting complexes put into operation, units } \\
{[13,14]}\end{array}$ \\
\hline & $\begin{array}{l}\text { The share of MSW processing enterprises in the structure of the } \\
\text { region's industry, \% [11] }\end{array}$ \\
\hline & $\begin{array}{l}\text { The share of products produced from MSW in the total volume } \\
\text { of products produced in the region, } \%\end{array}$ \\
\hline $\begin{array}{l}\text { Indicators that characterize the } \\
\text { level of financing of the waste } \\
\text { processing industry }\end{array}$ & $\begin{array}{l}\text { The share of attracted extra-budgetary funds in the total amount } \\
\text { of industry financing, } \% \text { [11] }\end{array}$ \\
\hline \multicolumn{2}{|c|}{ Social indicators of development of the industry } \\
\hline \multirow{5}{*}{$\begin{array}{l}\text { Indicators that characterize the } \\
\text { emergence of new jobs in the } \\
\text { region }\end{array}$} & $\begin{array}{l}\text { The number of people who can note an improvement in the } \\
\text { quality of life }[13,14]\end{array}$ \\
\hline & Number of jobs in the field of waste processing, units [11] \\
\hline & $\begin{array}{l}\text { The share of jobs in the field of waste processing from the total } \\
\text { number of jobs in the region, } \%[11]\end{array}$ \\
\hline & $\begin{array}{l}\text { Number of implemented environmental educational resources, } \\
\text { units* }\end{array}$ \\
\hline & Number of trained specialists in MSW management, pers. ${ }^{*}$ \\
\hline \multirow{4}{*}{$\begin{array}{l}\text { Indicators that characterize the } \\
\text { awareness and involvement of } \\
\text { stakeholders in the functioning } \\
\text { of the waste treatment system }\end{array}$} & $\begin{array}{l}\text { Number of information resources in the field of waste } \\
\text { management }[13,14]\end{array}$ \\
\hline & $\begin{array}{l}\text { The share of the population involved in the waste recycling } \\
\text { system, \% [11] }\end{array}$ \\
\hline & $\begin{array}{l}\text { Number of measures to attract stakeholders to the field of MSW } \\
\text { processing, units. * }\end{array}$ \\
\hline & $\begin{array}{l}\text { Coefficient of tariff reduction for collection, export and disposal } \\
\text { of MSW, RUB* }\end{array}$ \\
\hline \multicolumn{2}{|c|}{ Scientific, technical and innovative indicators of the industry development } \\
\hline \multirow{4}{*}{$\begin{array}{l}\text { Indicators that characterize the } \\
\text { organization of separate waste } \\
\text { collection }\end{array}$} & $\begin{array}{l}\text { Percentage of containers with digital software for separate } \\
\text { collection of MSW, \%* }\end{array}$ \\
\hline & $\begin{array}{l}\text { The share of specialized equipment with digital software for the } \\
\text { transportation of MSW, \%* }\end{array}$ \\
\hline & $\begin{array}{l}\text { The share of enterprises for sorting, processing and disposal of } \\
\text { MSW on the basis of digitalization of production, } \%^{*}\end{array}$ \\
\hline & $\begin{array}{l}\text { Number of implemented innovative projects in wastetech, } \\
\text { units.* }\end{array}$ \\
\hline
\end{tabular}

* - indicator proposed by the authors

The totality of the indicators presented in table 3 allows us to trace the dynamics of changes that occur at almost every stage of the waste life cycle as a result of the ongoing reform and assess the real state of the MSW management system.

\section{Conclusions}

The inter-municipal ecological waste processing cluster of the Voronezh region can be considered as a socially oriented cluster with a complex infrastructure. In this regard, an assessment of the effectiveness of the functioning of the waste management system should reflect the implementation of not only environmental, but also economic, social and scientific-technical directions of development of the region. 
The proposed indicators can become an important component of the waste management system in the Voronezh region and can be used for the following practical purposes:

- analysis and monitoring of the achievement of the objectives of the regional program for the modernization of the sphere of waste management and the adoption of effective management decisions;

- the formation of a single information base for various stakeholders involved in the waste management system;

- the rationale for the allocation of budgetary funds for IEWC subjects, depending on the effectiveness of their implementation of various programs for the development of the waste processing industry;

- assessing the effectiveness of the territorial scheme of waste management;

- development of the IEWC rating.

In the future, our research will be aimed at developing an algorithm for assessing the development of the sphere of safe waste management in the Voronezh region.

\section{References}

1. I. V. Kryuchkova, E. P. Smorodina, O. M. Belyantseva, Y. A. Andryunina, Problems and prospects for the development of a separate waste collection system as an element of the socio-economic development of the Voronezh region. Journal of Economy and entrepreneurship, 14(4), 456-461 (2020)

2. I. S. Frolova, Approaches to the formation and evaluation of the effectiveness of economic clusters, 21 st Century Initiatives, (2), 35-39 (2010)

3. L. S. Markov. Theoretical and methodological foundations of the cluster approach. Novosibirsk: IEOPP SB RAS, 300 (2015)

4. Yu. G. Lavrikova, Clusters as a market institution for the spatial development of the region's economy. Abstract of the dissertation, Ekaterinburg, 46 (2009)

5. E. A. Kurnosova, Evaluation of the effectiveness of the operation of aerospace clusters. Bulletin of Samarsky State University. Series "Economics and Management", 9/2(131), 97-105 (2015)

6. L. B. Leonova, V. A. Koksharov, Methodological approaches and criteria for assessing the formation and functioning of the socio-economic cluster in the housing and utilities sector. Bulletin USPTU. Science, education, economy. Series economy, 2(28), 7-13 (2019)

7. V. S. Prosalova, Alternative approaches to assessing the effectiveness of strategic management of cluster innovation, Internet Journal of Science, 1(9), 18 (2017)

8. I. Yu. Shvets, Qualitative criteria for assessing the effectiveness of the tourism cluster. Culture of the Black Sea peoples, 67, 139-142 (2005)

9. A. A. Lebedeva, D. A. Lebedev, Indicators of the state of the municipal waste management system, International Scientific Journal "Innovation Science", 5, 229-231 (2015)

10. A. V. Erygina, The system of indicators for solid municipal waste management, Bulletin of the Russian State Pedagogical University, 14(37), 75-78 (2007)

11. O. E. Goryacheva, T. A. Smirnova, O. V. Govorina, Monitoring indicators system development in the field of solid municipal waste processing, Petersburg Economic Journal, 3, 121-130 (2019)

12. The order of the Government of the Russian Federation of January 25, 2018 No. 84-r «On approval of the Industry Development Strategy for the processing, utilization and 
neutralization of production and consumption waste for the period until 2030». http://www.consultant.ru/document/cons_doc_LAW_289114/ (last accessed 06.21.2020)

13. Decree of the Government of the Russian Federation of April 15, 2014, 326 (as amended of March 31, 2020) «On approval of the state program of the Russian Federation“" Environmental Protection» (2014)

14. http://www.consultant.ru/document/cons_doc_LAW_162183/ (last accessed 21.06.2020)

15. Decree of the Government of the Voronezh region of $01.11 .2015, \mathbf{8 5 6}$ (as amended on March 30, 2020) «On approval of the state program of the Voronezh Region» Environmental Protection and Natural Resources (2015)

16. http://www.consultant.ru/regbase/cgi/online// (last accessed 21.06.2020)

17. L. P. Koroleva, Contribution to neo-industrial development: classification of effects, Scientific journal NRU ITMO. Series Economics and Environmental Management, 2, 29-38 (2017) DOI: 10.17586 / 2310-1172-2017-10-2-29-38

18. E. A. Avdeeva, T. A. Averina, T. E. Davydova, E. N. Zhutaeva, Automation of Russian industry as an indispensable condition for sustainable economic development in the digital environment, IOP Conf. Series: Materials Science and Engineering, 862, 042041 (2020) doi:10.1088/1757-899X/862/4/042041 